\title{
ANALISIS POTENSI DAN DAYASAING KECAMATAN SEBAGAI PUSAT PERTUMBUHAN SATUAN WILAYAH PENGEMBANGAN (SWP) KABUPATEN MALANG
}

\author{
Sutikno \\ Fakultas Ekonomi Universitas Muhamadiyah Malang \\ Maryunani \\ Fakultas Ekonomi Universitas Brawijaya
}

\begin{abstract}
In terms of administration, Malang is divided into two regions, Malang City and Malang Regency. Although the regions are different, economically two regions can not separated because almost all economic activities are concentrated at Malang City. This has impacts on the economic gap between Malang City and Malang Regency. With respect to gap, the research was conducted to analyze the growth center of Regional Development Unit (RDU) of the Malang City, based on two development directions: identifying sectoral economic potentials and that for regional sowol potentials.

In terms of regional aspects, the description of development centers in each RDU are: (1) Ngantang Sub-district is a priority for the development center of RDU I; (2) Singosari Sub-district is a priority for the development center of northern RDU II; (3) Pakisaji Sub-district is a priority for the development center of southern RDU II; (4) Poncokusumo Sub-district is a priority for the development center of RDU IV; (5) Kepanjen Sub-district is a priority for the development center of RDU V; (6) Pagelaran Sub-district is a priority for the development center of RDU VII; and (7) Turen Sub-district is a priority for the development center of RDU VIII.

Since the results has policy impacts, the government of the Malang Regency should decide regional development policies referring to the regional development concept based on the economic and regional potentials so that it can give priorities to potential districts to be acted as development centers. By implementing the policy, it is expected that economic activities will not be concentrated on one development point, the Malang City as the only development point.
\end{abstract}

Keywords: growth center, Regional Development Unit (RDU), sectoral economic potentials and regional potentials

\section{A. LATAR BELAKANG}

Indonesia yang tergolong sebagai negara sedang berkembang, pada awal proses pembangunannya lebih condong untuk memilih atau mengarah pada strategi pembangunan ekonomi tidak seimbang. Pemilihan strategi tersebut bisa dilihat dari kebijakan-kebijakan dalam proses pembangunan, misalnya mendorong sektor industri menjadi sektor pemimpin (leading sector), sehingga bisa mendorong pertumbuhan setor-sektor lain. Selain itu dalam konteks spasial (ruang), dengan terbatasnya sumberdaya pembangunan maka kebijakan pembangunan yang diambil adalah menentukan daerah-daerah tertentu sebagai pusat-pusat pertumbuhan. 


\section{Journal of Indonesian Applied Economics \\ Vol.1 No.1 Oktober 2007, 1-17}

Sedangkan bagi bukan daerah pusat pertumbuhan, dampak negatif yang ditimbulkan adalah terserapnya sumberdaya pembangunan (seperti modal dan tenaga kerja ahli) ke daerah pusat pertumbuhan. Akibatnya kegiatan ekonomi terkonsentrasi (teraglomerasi) di daerah perkotaan (pusat pertumbuhan), akibatnya trickle down effect yang diharapkan tidak tercipta. Fenomena tersebut mengindikasikan tidak ada pergerakan pertumbuhan ekonomi dari pusat pertumbuhan (kota) ke daerah bukan pusat pertumbuhan (desa), bahkan justru memperparah kesenjangan ekonomi antar daerah.

Dengan kata lain, kebijakan pembangunan regional kita telah membentuk daerah-daerah nodal. Daerah nodal adalah areal-areal yang strukturalnya terdiri dari atas areal inti dengan areal-areal sekitarnya yang melengkapi, dalam arti ekonomi yang terpadu dengan areal inti itu (Soepono, 1999). Sedangkan menurut Arsyad, daerah nodal adalah daerah dianggap sebagai suatu ekonomi ruang yang dikuasai oleh satu atau beberapa pusat kegiatan ekonomi. Contoh dari daerah nodal antara lain; kawasan Jabotabek yang menjadikan Jakarta sebagai pusat kegiatan ekonominya, kawasan Gerbangkertasusila yang menjadikan Surabaya sebagai pusat kegiatan ekonominya.

Fenomena terciptanya daerah nodal tidak hanya terjadi pada wilayah propinsi, tetapi juga terjadi pada wilayah kabupaten/kota, dimana biasanya pusat kegiatan ekonomi terjadi di daerah kota. Untuk kawasan kabupten/kota fenomena tersebut khususnya terjadi pada kabupaten-kabupaten yang mempunyai wilayah yang luas. Kabupaten yang mempunyai wilayah yang luas biasanya membagi dua wilayah secara administratif, yaitu wilayah kota (kotamadya) dan wilayah kabupaten. Wilayah kota inilah yang kemudian dijadikan sebagai pusat kegiatan ekonomi, sedangkan daerah kabupaten sebagai daerah pendukung.

Potret kondisi di atas salah satunya terjadi pada daerah Malang, dimana wilayah Kota Malang dijadikan sebagai pusat kegiatan ekonomi, karena hampir semua infrastruktur yang menunjang kegiatan ekonomi (mulai dari pasar input sampai pasar output) ada diwilayah Kota Malang. Akibatnya laju pertumbuhan ekonomi Kota Malang menjadi lebih tinggi dibanding kabupaten Malang seperti yang terlihat pada tabel 1 di bawah ini.

Tabel 1. PDRB Per Kapita Kabupaten Malang dan Kota Malang Tahun1993 - 2000

\begin{tabular}{c|c|c}
\hline Tahun & Kabupaten Malang & Kota Malang \\
\hline 1993 & 1.010 .882 & 2.597 .577 \\
\hline 1994 & 1.114 .880 & 2.975 .089 \\
\hline 1995 & 1.249 .811 & 3.392 .269 \\
\hline 1996 & 1.396 .996 & 3.896 .038 \\
\hline 1997 & 1.608 .440 & 4.295 .890 \\
\hline 1998 & 2.611 .731 & 6.741 .855 \\
\hline 1999 & 2.685 .733 & 9.455 .943 \\
\hline 2000 & 3.080 .197 & 7.914 .313 \\
\hline
\end{tabular}

Sumber : Biro Pusat Statistik

Data di atas menunjukkan bahwa dari indikator pendapatan per kapita, Kota Malang memiliki pertumbuhan yang lebih tinggi di banding Kabupaten Malang. Hal tersebut bisa terlihat dari PDRB per kapita Kota Malang selama periode 1993-2000, selalu lebih besar dari pada PDRB per kapita Kabupaten Malang.

Selain membandingkan PDRB per kapita, perbedaan pertumbuhan ekonomi antara Kota Malang dengan Kabupaten Malang bisa juga membandingkan Pendapatan Asli Daerah (PAD) kedua daerah tersebut, seperti terlihat pada tabel dibawah ini. 


\section{Analisis Daya Saing dan Potensi Daerah}

Tabel 2. Pendapatan Asli Daerah (PAD) Kabupaten Malang dan Kota Malang Tahun 1998 - 2002 (Dalam Milyar Rupiah)

\begin{tabular}{c|c|c}
\hline Tahun & Kabupaten Malang & Kota Malang \\
\hline 1998 & 14,27 & 18,72 \\
\hline 1999 & 17,71 & 17,99 \\
\hline 2000 & 13,15 & 16,54 \\
\hline 2001 & 26,70 & 27,99 \\
\hline 2002 & 25,68 & 26,85 \\
\hline
\end{tabular}

Sumber : Biro Pusat Statistik

Data di atas menunjukkan, Pendapatan Asli Daerah Kota Malang dalam periode 1998 - 2002 selalu lebih besar dibanding Kabupaten Malang. Fenomena ini bisa juga dijadikan acuan bahwa pertumbuhan ekonomi Kota Malang lebih baik dibanding Kabupaten Malang.

Fenomena perbedaan pertumbuhan ekonomi antara Kota dan Kabupaten Malang, bila dikaitkan dengan otonomi daerah, setidaknya ada dua persoalan penting yaitu; pertama, Undang-Undang Otonomi Daerah yang diharapkan mampu mencairkan pusat pertumbuhan yang selama ini terpusat pada daerah tertentu, dengan cara mengembalikan sumberdaya-sumberdaya pembangunan ke daerah bukan pusat pertumbuhan akan mengalami kendala. Hal tersebut disebabkan karena daerah-daerah yang selama ini menjadi pusat pertumbuhan justru dengan otonomi daerah, ada kecenderungan semakin memperkuat "ikatannya" terhadap sumberdaya pembangunan yang ada di daerahnya agar tidak pindah ke daerah lainnya. Hal tersebut semua dilakukan demi tuntutan otonomi.

Demikian pula yang terjadi pada Kota Malang dan Kabupaten Malang. Kota Malang tidak akan membiarkan begitu saja sumberdaya pembangunannya yang sudah ada di wilayahnya akan mudah pidah kembali ke Kabupaten Malang, bahkan pemerintah Kota Malang dengan berbagai upaya terus meningkatkan daya tarik pelaku ekonomi untuk melakukan aktivitas ekonomi di daerahnya. Dengan kata lain Kota Malang dengan potensi yang dimilikinya akan terus menyerap sumberdaya pembangunan (tenaga kerja, modal, dan bahan baku) dari daerah terdekat yaitu Kabupaten Malang. Padahal secara administrative kedua daerah tersebut terpisah dan memiliki tanggung jawab masingmasing dalam mengelola daerahnya. Kedua, kegiatan-kegiatan ekonomi yang terkonsentrasi (aglomerasi) di pusat-pusat pertumbuhan sulit untuk pindah, karena daerah-daerah pertumbuhan merupakan pusat pasar baik input maupun output yang sangat potensial bagi pelaku ekonomi.

\section{Rumusan Masalah}

Pengembangan kebijakan SWP memiliki dua arah pengembangan yaitu mengidentifikasi potensi ekonomi dan potensi wilayah. Untuk pengembangan tersebut ada beberapa permasalahan yang perlu diketahui jawabannya. Permasalahan-permasalahan tersebut dapat dirumuskan sebagai berikut:

1. Bagaimana struktur ekonomi dan pola pertumbuhan di masing-masing Satuan Wilayah Pengembangan (SWP) di Kabupaten Malang.

2. Apa yang menjadi sektor dan sub sektor ekonomi unggulan di masing-masing Satuan Wilayah Pengembangan (SWP) di Kabupaten Malang.

3. Bagaimana potensi dan daya saing masing-masing kecamatan sebagai prioritas pusat pertumbuhan di setiap Satuan Wilayah Pengembangan (SWP).

\section{Tujuan Penelitian}

Bertolak dari rumusan masalah di atas, tujuan yang ingin di capai dalam penelitian adalah:

1. Untuk mengetahui bagaimana struktur dan pola pertumbuhan ekonomi masing-masing Satuan Wilayah Pengembangan (SSWP).

2. Untuk mengetahui sektor dan sub sektor ekonomi unggulan di masing-masing Satuan Wilayah Pengembangan (SWP) 


\section{Journal of Indonesian Applied Economics \\ Vol.1 No.1 Oktober 2007, 1-17}

3. Untuk mengetahui potensi dan daya saing masing-masing kecamatan sebagai prioritas pusat pertumbuhan pada masing-masing Satuan Wilayah Pengembangan (SWP).

\section{B. Tinjauan Teoritis}

\section{Teori Basis Ekonomi}

Teori basis ini didasari oleh pemikiran J.S.Mill yaitu bahwa dalam memecahkan masalah pertumbuhan dan pemerataan regional diisyaratkan adanya perdagangan antar daerah, dengan mewujudkan spesialisasi daerah. Dasar pemikiran teori basis ekonomi menurut Kadariah (1985:70) adalah karena industri basis menghasilkan barang dan jasa baik untuk pasar di dalam maupun di luar daerah, maka maka penjualan hasil keluar daerah itu akan mendatangkan arus pendapatan kedalam daerah tersebut. Arus pendapatan ini menyebabkan baik kenakian konsumsi maupun kenaikan investasi di daerah itu, yang pda gilirannya akan menaikan pendapatan dan kesempatan kerja. Jika di daerah itu ada pengangguran, maka kesempatankerja yang baru itu dapat menampungnya, atau jika di daerah itu tidak terdapat pengangguran maka daerah itu mempunyai daya tarik bagi orang-orang dari luar daerah yang mencari pekerjaan. Kenaikan pendapatan itu tidak hanya menaikkan permintaan terhadap hasil industri basis melainkan juga akan menaikkan permintaan hasil industri lokal non basis dan permintaan ini selanjutnya akan menaikkan investasi di industri-industri non basis. Dengan kata lain penanaman modal di sektor-sektor lokal merupakan investasi sebagai akibat kenaikan pendapatan dari industri-industri basis.

Bertambah banyaknya sektor basis di suatu daerah akan menambah arus pendapatan ke dalam daerah yang bersangkutan, menambah permintaan terhadap barang dan jasa didalamnya, meningkatkan nilai investasi dan menimbulkan kenaikan volume kegiatan bukan basis. Dengan demikian sesuai dengan namanya kegiatan basis mempunyai peran sebagai penggerak pertama dimana setiap perubahan mempunyai efek multiplier terhadap perekonomian agregat. Berdasarkan gagasan inilah, maka para ahli berpendapat bahwa sektor-sektor basis inilah yang seharusnya dikembangkan di suatu daerah.

\section{Teori Lokasi Pertumbuhan}

Teori lokasi merupakan cabang ilmu ekonomi regional paling tua yang dikembangkan sejak abad kesembilan belas oleh H.W. Richardson. Teori ini diilhami oleh pertanyaan Weber, yaitu pertanyaan mengapa pabrik-pabrik cenderung berlokasi saling berdekatan. Teori lokasi adalah teori yang menjelaskan di mana dan bagaimana suatu aktivitas ekonomi memilih lokasinya secara optimal. Jawaban terhadap pertanyaan tersebut adalah penting bagi para pengambil keputusan publik, perencana lembaga-lembaga perdagangan eceran (yang ingin membuat pilihan lokasi yang tepat) maupun pengembang-pengembang komonitas serta real estate, yang berharap untuk dapat menarik bisnis ke kawasan-kawasan mereka (Soepono, 1999). Dengan demikian lokasi perusahaan-perusahaan atau kegiatan ekonomi memerankan peranan penting bagi lokasi daerah/kota. Keputusan-keputusan lokasi perusahaan-perusahaan dan aktivitas ekonomi seharusnya menyebabkan timbul dan berkembangnya kota-kota dan daerah-daerah.

Faktor-faktor lokasi menurut Soepono, dapat dikelompokkan menjadi dua orientasi yaitu, pertama, orientasi transportasi, yang dimaksud dengan orientasi transportasi adalah bahwa transportasi merupakan porsi terbesar dari biaya total dari organisasi suatu aktivitas ekonomi, sehingga menjadi penentu keputusan lokasi. Faktor-faktor lokasi yang berorientasi transportasi antara lain; faktor transportasi, faktor sumberdaya, faktor pasar, dan faktor tenaga kerja. Kedua, orientasi masukan lokal, yang dimaksud denganorientasi masukan lokal adalah bahwa masukan lokal itulah yang merupakan persentase terbesar dari biaya total dan disebut lokal bila input itu tidak dapat secara efisien diangkut dari lokasi satu ke lokasi lain. 


\section{Analisis Daya Saing dan Potensi Daerah \\ Sutikno dan Maryunani}

\section{Teori Kutub Pertumbuhan}

Inti teori yang dikemukakan oleh Perroux dapat dijabarkan sebagai berikut; 1) Dalam proses perubahan akan timbul industri unggulan yang merupakan penggerak utama dalam pembangunan suatu daerah. Karena keterkaitan antara industri sangat erat, maka perkembangan industri unggulan akan mempengaruhi perkembangan industri lain yang berhubungan erat dengan industri unggulan tersebut. 2) Pemusatan industi pada suatu daerah akan mempercepat pertumbuhan perekonomian, karena pemusatan industri akan mencipakan pola konsumsi yang berbeda antar daerah, sehingga perkembangan industri di daerah tersebut akan mempengaruhi perkembangan daerah-daerah lainnya. 3) Perekonomian merupakan gabungan dari sistem industri yang relatif aktif (industri unggulan) dengan industri-industri yang relatif pasif yaitu industri yang tergantung dengan industri unggulan/ pusat pertumbuhan. Daerah yang relatif maju/aktif akan mempengaruhi daerah-daerah yang relatif pasif.

Menurut Badrudin (1999:175), terdapat dua hal penting yang berkaitan dengan kutub pertumbuhan: pertama, kutub pertumbuhan merupakan sekelompok kegiatan industri yang mempunyai keterkaitan ke depan (forward lingkage) dan keterkaitan ke belakang (backward lingkage) yang kuat terhadap sebuah industri yang unggul, sehingga akan mempunyai kemampuan untuk menggerakkan aktivitas perekonomian dan sekaligus memacu pertumbuhan ekonomi pada suatu negara. Kedua, kelompok industri tersebut akan berupaya memilih lokasi pada kota-kota besar dengan mempertimbangkan kemudahan berbagai prasarana dan fasilitas, namun tetap memperhatikan hubungan dengan daerah pendukung (hinterland) sebagai salah satu pemasok input atau sumberdaya, konsep ini dikenal dengan aglomerasi ekonomi.

Sedangkan Myrdal menekankan analisisnya kepada faktor-faktor yang menyebabkan timbulnya ketidakseimbangan di berbagai daerah. "Suatu daerah yang lebih maju akan berkembang dengan lebih cepat dari yang kurang maju karena faktor-faktor backwash effect lebih kuat dari faktor yang menimbulkan spread efect'”' (Sadono Sukirno, 1985: 66-67).

\section{METODE PENELITIAN DANANALISIS DATA}

Penelitian ini mempunyai tujuan pokok untuk mengidentifikasi sektor dan sub sektor unggulan di masing-masing Satuan Wilayah Pengembangan (SWP) dan menentukan kecamatan potensial di setiap Satuan Wilayah Pengembangan (SWP) sebagai prioritas pusat pertumbuhan ekonomi. Penentuan kecamatan potensial untuk dijadikan pusat pertumbuhan, merupakan suatu pendekatan yang digunakan dalam penelitian ini dalam upaya mengurangi kesenjangan pertumbuhan antar wilayah di kawasan Malang. Pendekatan ini dilakukan berdasarkan hipotesa bahwa kawasan Malang yang mempunyai luas wilayah besar hanya mempunyai satu pusat pertumbuhan ekonomi yaitu di wilayah Kota Malang. Model penentuan wilayah potensial untuk dijadikan sebagai pusat pertumbuhan ekonomi secara ringkas dapat dilihat pada gambar 1.

\section{Alat Analisis}

Studi ini menggunakan beberapa metode analisis dalam menjawab tujuan yang akan dicapai. Alat analisis tersebut meliputi: Tipologi Klassen, Location Quatient (LQ), Shift-Share (S-S), Analisis Scalogram, dan Analisis Daya Saing.

1) Analisis Tipologi Klassen

Alat analisis ini adalah untuk mengetahui gambaran pola dan struktur pertumbuhan ekonomi ekonomi daerah.. Kuncoro (1997) menggunakan alat analisis ini untuk menunjukkan kinerja pertumbuhan ekonomi 27 propinsi di Indonesia. Dengan membandingkan ratio pendapatan perkapita dan ratio pertumbuhan. Dalam penelitiannya perekonomian propinsi di Indonesia diklasifikasikan ke dalam 4 kelompok. 1) Low growth, high income, 2) High growt, high income, 3) High growth, low income dan 4) Low growth, low income. 
2) Analisis Location Quotient (LQ)

Teknik analisis ini digunakan untuk menentukan kategori suatu sektor termasuk dalam sektor basis atau bukan basis. Formulasi dari teknik analisis tersebut adalah: (Iwan Jaya Azis, 1993 : 3)

$$
\mathrm{LQ}_{\mathrm{i}}^{\mathrm{J}}=\frac{\mathrm{VA}_{\mathrm{i}}^{\mathrm{J}} / \mathrm{VA}_{\mathrm{i}}^{\mathrm{I}}}{\mathrm{PDRB}^{\mathrm{J}} / \mathrm{PDRB}^{\mathrm{I}}}
$$

Keterangan :

$\mathrm{LQ}_{\mathrm{i}}^{\mathrm{J}}=$ Location Quatient sektor $i$ di daerah $J$

$\mathrm{VA}_{\mathrm{i}}^{\mathrm{J}}=$ Nilai tambah sektor $\mathrm{i}$ di daerah $J$

$\mathrm{VA}^{\mathrm{I}}=$ Nilai tambah sektor $i$ di tingkat kabupaten

PDRB $^{\mathrm{I}} \quad=$ Produk Domestik Regional Bruto di daerah $J$

$\mathrm{PDRB}^{\mathrm{I}} \quad=$ Produk Domestik Regional Bruto Kabupaten

Dari hasil perhitungan yang diperoleh dapat diartikan dalam dua kategori, yaitu:

- $\quad$ Bila nilai LQ lebih kecil atau sama dengan 1, menunjukkan bahwa sektor tersebut bukan sektor basis.

- $\quad$ Bila nilai LQ lebih besar dari 1, menunjukkan bahwa sektor tersebut adalah sektor basis.

3) Analisis Shift-share (S-S)

Metode analisis ini dapat digunakan untuk memproyeksikan pertumbuhan ekonomi suatu daerah dan sebagai alat analisis dalam riset pembangunan pedesaan (Tulus Tambunan, 1996).

Teknik analisis ini diawali dengan perhitungan perubahan PDRB suatu sektor di suatu daerah antara 2 periode, yaitu:

$$
\begin{aligned}
& { }^{\mathrm{C}} \mathrm{Q}_{\mathrm{ij}}^{\mathrm{t}}=\mathrm{Q}_{\mathrm{ij}}^{\mathrm{t}}-\mathrm{Q}_{\mathrm{ij}}^{0} \\
& \text { Dimana: } \\
& \text { " } \mathrm{Q}_{\mathrm{ij}}^{\mathrm{t}}=\text { Perubahan PDRB } \\
& \mathrm{Q}^{\mathrm{t}}{ }^{i j}=\text { PDRB sektor } i \text { daerah } j \text { periode tahun } t \\
& \mathrm{Q}^{0}{ }_{\mathrm{ij}}=\text { PDRB sektor } \mathrm{i} \text { daerah } \mathrm{j} \text { periode tahun dasar }
\end{aligned}
$$

Teknik analisis ini dibagi menjadi 3 komponen utama, yaitu pangsa regional, pergeseran proporsional dan pergeseran yang berbeda, maka persamaan (1) dapat diperluas menjadi:

$$
\Delta Q_{i j}=Q_{i j}\left\{\frac{Y_{t}}{Y_{0}}-1\right\}+Q_{i j}\left\{\frac{Q_{i}}{Q^{0}}-\frac{Y_{t}}{Y_{0}}\right\}+Q_{i j}\left\{\frac{Q_{i j}}{Q_{i j}}-\frac{Q}{Q}\right\} .
$$

Persamaan (2) dapat dipisahkan menjadi 3 komponen utama yang mempengaruhi pertumbuhan ekonomi daerah:

$$
\begin{aligned}
& R S_{i j}=Q_{i j}^{0}\left\{\frac{Y_{t}}{Y_{0}}-1\right\} \ldots \ldots . \\
& P S_{i j}=Q_{i j}^{0}\left\{\frac{Q_{i}^{t}}{Q_{i}^{0}}-\frac{Y_{t}}{Y_{0}}\right\} \ldots \\
& D S_{i j}=Q_{i j}^{0}\left\{\frac{Q_{i j}^{t}}{Q_{i j}^{0}}-\frac{Q_{i}^{t}}{Q_{i}^{0}}\right\} .
\end{aligned}
$$

Dimana:

$Y_{t}=$ PDRB Kabupaten periode tahun $t$ 


\section{Analisis Daya Saing dan Potensi Daerah \\ Sutikno dan Maryunani}

$Y_{0} \quad=$ PDRB Kabupaten pada periode tahun dasar

$Q_{i}^{t} \quad=$ PDRB Kabupaten sektor $i$ pada tahun $t$

$Q_{i}^{0} \quad=P D R B$ Kabupaten sektor $i$ pada tahun dasar

$Q_{i j}^{t}=$ PDRB SWP sektor $i$ pada tahun $t$

$Q_{i j}^{0}=$ PDRB SWP sektor $i$ pada tahun dasar

Dari hasil perhitungan tersebut dapat diartikan bahwa bila:

1) $P S<0$ maka sektor tersebut tumbuh relatif lambat di tingkat kabupaten

2) $P S>0$ maka sektor tersebut tumbuh relatif cepat di tingkat kabupaten

3) $D S<0$ maka sektor tersebut memiliki pertumbuhan yang lebih lambat dibandingkan sektor yang sama di daerah lain atau dengan kata lain sektor tersebut tidak mempunyai keuntungan lokasional yang baik.

4) DS $>0$ maka sektor tersebut memiliki pertumbuhan yang lebih cepat dibandingkan sektor yang sama di daerah lain atau dengan kata lain sektor tersebut mempunyai keuntungan lokasional yang baik.

5) $R S<$ " $Q_{i j}^{t} \quad$ maka pertumbuhan produksi di daerah tersebut cenderung mendorong pertumbuhan kabupaten.

6) $R S>$ " $Q_{i j}^{t} \quad$ maka pertumbuhan produksi di daerah tersebut cenderung akan menghambat pertumbuhan propinsi.

4) Analisis Daya Saing

Analisis daya saing menurut Institute of Management Development (IMD) dengan publikasinya "Word Competitiveness Yearbook" melihat daya saing merupakan kemampuan suatu negara dalam menciptakan nilai tambah dalam rangka menambah kekayaan nasional dengan cara mengelola aset dan proses, daya tarik dan agresivitas, globality dan proximity, serta dengan mengan mengintegrasikan hubungan-hubungan tersebut ke dalam suatu model ekonomi dan sosial. Dengan perkataan yang lebih sederhana, daya saing nasional adalah suatu konsep untuk mengukur dan membandingkan seberapa baik suatu negara dalam menyediakan suatu iklim tertentu yang kondusif untuk mempertahankan daya saing domestik maupun global kepada perusahaanperusahaan yang berada di wilayahnya (lihat Piter Abdullah dk 2002:12).

Alat analisis ini digunakan Departemen Perdagangan dan Industri Inggris (UK-DTI) dalam mengukur daya saing antar regional di Inggris, yang menerbitkan "Regional Competitiveness Indicators", serta Centre for Urban and Regional Studies (CURDS), Inggris, dengan publikasinya "The Competitiveness Project: 1998 Regional Benchmarking Report". (lihat Piter Abdullah dk 2002 : 13). Selain itu alat analisis ini juga digunakan oleh Pusat Pendidikan dan Studi Kebanksentralan Bank Indonesia untuk mengukur daya saing seluruh daerah propinsi yang ada di Indonesia.

Penelitian ini akan menganalisis daya saing seluruh kecamatan yang ada pada wilayah kabupaten Malang. Analisis daya saing kecamatan dalam penelitian ini menggunakan indikatorindikator sebagai berikut: 1) Indikator Keterbukaan, 2) Indikator Sistem Keuangan, 3) Indikator Sumberdaya Manusia, 4) Indikator Kelembagaan, 5) Indikator Keamanan, dan 6) Indikator Lingkungan

\section{5). Analisis Scalogram}

Analisis ini bertujuan untuk mengidentifikasi peranan suatu kecamatan berdasarkan pada kemampuan masing-masing kecamatan dalam memberikan pelayanan kepada masyarakat. Asumsinya jika suatu kecamatan mempunyai berbagai fasiltas yang relatif lengkap di bandingkan dengan kecamtan lainnya, maka kecamatan tersebut mampu berperan sebagai suatu pusat pertumbuhan pada kawasan tersebut.

Menurut Blakely (1994: 94-99), alat analisis scalogram membahas mengenai fasilitas perkotaan yang dimiliki suatu daerah sebagai indikator difungsikannya daerah tersebut sebagai salah satu pusat pertumbuhan. 
Dalam penelitian ini, alat analisis scalogram akan digunakan untuk menghitung tingkat kelengkapan fasilitas kecamatan yang akan dikelompokkan menjadi dua kelompok, yaitu: 1) Fasilitas yang berkaitan dengan aktivitas ekonomi, 2) Fasilitas yang berkaitan dengan aktivitas sosial.

\section{HASIL PENELITIAN}

\section{Struktur Ekonomi SWP}

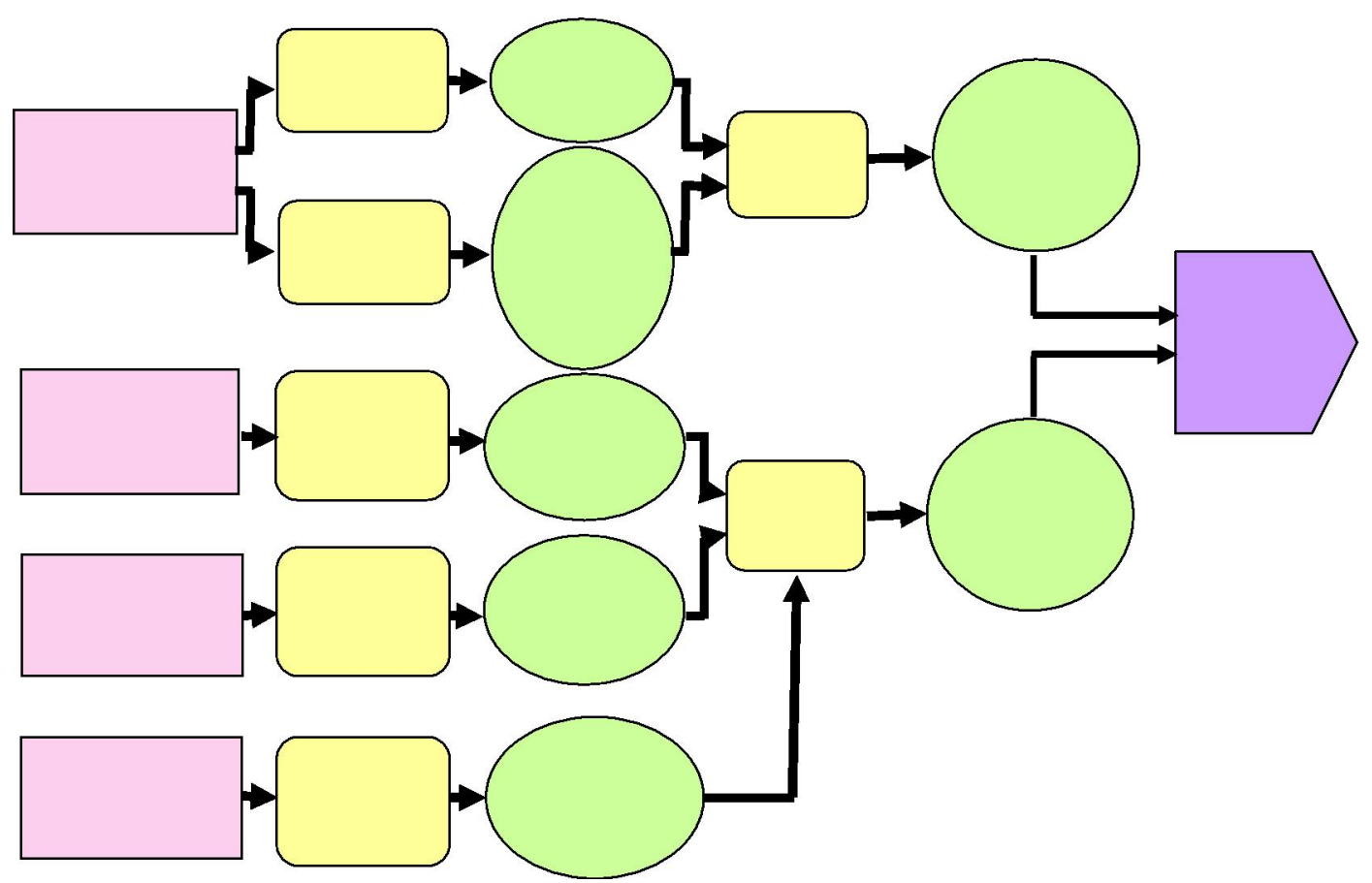

Gambar 1. Model Penentuan Sub Sektor Unggulan dan Kecamatan Prioritas Sebagai Pusat Pertumbuhan Ekonomi Di Masing-Masing Satuan Wilayah Pengembangan (SWP)

Setelah melakukan perhitungan dan analisis kontribusi masing-masing sektor maupun kelompok sektor ekonomi terhadap total Produk Domestik Regional Bruto (PDRB) di masing-masing Satuan Wilayah Pengembangan (SWP) maka dapat diperoleh gambaran struktur ekonomi masing-masing S

Berdasarkan tabel 3, sektor pertanian merupakan sektor yang memberikan kontribusi terbesar PDRB di semua SWP kecuali SWP III. Untuk SWP III sektor yang memberikan kontribusi terbesar terhadap PDRB nya adalah sektor industri pengolahan. Hal ini menggambarkan bahwa sektor pertanian masih merupakan sektor primadona atau leanding sektor di Kabupaten Malang.

Namun apabila dilihat dari kontribusi berdasarkan kelompok sektor ekonomi, ternyata kelompok sektor tersier yang memberikan kontribusi terbesar terhadap PDRB di semua SWP, kemuadian disusul oleh kelompok sektor primer dan sekunder. Kecuali untuk SWP II dan SWP III, untuk kedua SWP ini sektor sekunder yang mempati urutan 2 dan kemudian disusul oleh sektor primer. Besarnya kontribusi kelompok sektor tersier disebabkan karena lebih banyaknya sektor yang tergolong sektor tersier. Sektor tersier terdiri dari 4 sektor, sementara sektor primer hanya terdiri dari 2 sektor dan sektor sekunder terdiri dari 3 sektor.

Sektor pertanian, industri pengolahan, dan perdagangan, hotel, dan restoran, merupakan sektor yang memberikan kontribusi terbesar terhadap kelompok sektornya masing-masing. Keadaan tersebut terjadi pada semua SWP yang ada di kabupaten Malang. Keadaan ini memberikan gambaran bahwa aktivitas perekonomian di masing-masing SWP di kabupaten Malang cenderung bersifat homogen. 


\section{Analisis Daya Saing dan Potensi Daerah \\ Sutikno dan Maryunani}

Dengan kata lain aktivitas ekonomi di semua SWP di dominasi oleh sektor pertanian, industri pengolahan, dan perdagangan, hotel dan restoran.

Tabel 3. Struktur Ekonomi Masing-Masing Satuan Wilayah Pengembangan Di Kabupaten Malang

\begin{tabular}{|c|c|c|c|c|c|c|}
\hline \multirow{2}{*}{ SWP } & \multicolumn{2}{|c|}{$\begin{array}{c}\text { Kontribusi Terbesar Thd } \\
\text { PDRB }\end{array}$} & \multicolumn{3}{|c|}{ Kontribusi Terbesar Thd Kelompok Sektor } & \multirow{2}{*}{$\begin{array}{l}\text { Struktur } \\
\text { Ekonomi }\end{array}$} \\
\hline & Sektor & $\begin{array}{c}\text { Kelomp } \\
\text { ok } \\
\text { Sektor }\end{array}$ & Primer & Sekunder & Tersier & \\
\hline I & Pertanian & Tersier & Pertanian & Ind.Pengolahan & $\begin{array}{l}\text { Perdagangan, Hotel } \\
\text { dan Restoran }\end{array}$ & $\mathrm{T}, \mathrm{P}, \mathrm{S}$ \\
\hline II & Pertanian & Tersier & Pertanian & Ind.Pengolahan & $\begin{array}{l}\text { Perdagangan, Hotel } \\
\text { dan Restoran }\end{array}$ & $\mathrm{T}, \mathrm{S}, \mathrm{P}$ \\
\hline III & $\begin{array}{l}\text { Industri } \\
\text { Pengolahan }\end{array}$ & Tersier & Pertanian & Ind.Pengolahan & $\begin{array}{l}\text { Perdagangan, Hotel } \\
\text { dan Restoran }\end{array}$ & $\mathrm{T}, \mathrm{S}, \mathrm{P}$ \\
\hline IV & Pertanian & Tersier & Pertanian & Ind.Pengolahan & $\begin{array}{l}\text { Perdagangan,Hotel } \\
\text { dan Restoran }\end{array}$ & $\mathrm{T}, \mathrm{P}, \mathrm{S}$ \\
\hline $\mathrm{V}$ & Pertanian & Tersier & Pertanian & Ind.Pengolahan & $\begin{array}{l}\text { Perdagangan,Hotel } \\
\text { dan Restoran }\end{array}$ & $\mathrm{T}, \mathrm{P}, \mathrm{S}$ \\
\hline $\mathrm{VI}$ & Pertanian & Tersier & Pertanian & Ind.Pengolahan & $\begin{array}{l}\text { Perdagangan, Hotel } \\
\text { dan Restoran }\end{array}$ & $\mathrm{T}, \mathrm{P}, \mathrm{S}$ \\
\hline VII & Pertanian & Tersier & Pertanian & Ind.Pengolahan & $\begin{array}{l}\text { Perdagangan, Hotel } \\
\text { dan Restoran }\end{array}$ & $\mathrm{T}, \mathrm{P}, \mathrm{S}$ \\
\hline VIII & Pertanian & Tersier & Pertanian & Ind.Pengolahan & $\begin{array}{l}\text { Perdagangan,Hotel } \\
\text { dan Restoran }\end{array}$ & $\mathrm{T}, \mathrm{P}, \mathrm{S}$ \\
\hline
\end{tabular}

Keterangan: $\mathrm{P}=$ Sektor primer

$\mathrm{S}=$ Sektor Sekunder

$\mathrm{T}=$ Sektor tersier

\section{Tipologi Satuan Wilayah Pengembangan}

Alat analisis Tipologi Klassen digunakan untuk mengetahui klasifikasi daerah berdasarkan dua indikator utama, yaitu pertumbuhan ekonomi dan pendapatan atau produk domestik regional bruto per kapita daerah. Dengan menentukan rata-rata pertumbuhan ekonomi sebagai sumbu vertikal dan rata-rata produk domestik regional bruto (PDRB) per kapita sebagai sumbu horisontal, daerah dalam hal ini kecamatan yang diamati dapat dibagi menjadi empat klasifikasi/golongan, yaitu: daerah/ kecamatan yang cepat maju dan cepat tumbuh (high growth and high income), daerah/kecamatan maju tapi tertekan (high income but low growth), daerah/kecamatan yang berkembang cepat (high growth but low income), dan daerah/kecamatan yang relatif tertinggal (low growth and low income) (Kuncoro dan Aswandi, 2002:27-43).

Kriteria yang digunakan untuk menggolongkan SWP dalam penelitian mengenai "Analisis Pengembangan Kebijakan Satuan Wilayah Pengembangan (SWP) Kabupaten Malang Dalam Upaya Mengurangi Kesenjangan Pertumbuhan Ekonomi Antar Wilayah" adalah pertumbuhan ekonomi dan pendapatan per kapita dari masing-masing SWP. Pertumbuhan ekonomi dan pendapatan per kapita tersebut dibandingkan dengan pertumbuhan ekonomi dan pendapatan rata-rata tingkat Kabupaten.

Pertumbuhan PDRB dan perkembangan Pendapatan per Kapita Kabupaten Malang dan masingmasing Satuan Wilayah Pengembangan selama kurun waktu 2000 sampai dengan 2002, dapat dilihat pada tabel 4 . 
Tabel 4.Laju Pertumbuhan dan Pendapatan Per Kapita Kabupaten Malang Masing-Masing SWP

\begin{tabular}{c|l|c|c|l}
\hline NO & \multicolumn{1}{|c|}{ Wilayah } & $\begin{array}{c}\text { Laju } \\
\text { Pertumbuhan }\end{array}$ & $\begin{array}{c}\text { Pendapatan per } \\
\text { Kapita }\end{array}$ & Klasifikasi Wilayah \\
\hline 1 & Kabupaten Malang & 8.208 & 1201913.56 & - \\
\hline 2 & $\begin{array}{l}\text { SWP Ngantang \& } \\
\text { sekitarnya }\end{array}$ & 8.753 & 1144154.31 & Daerah Berkembang Cepat \\
\hline 3 & $\begin{array}{l}\text { SWP Lingkar Kota } \\
\text { Malang }\end{array}$ & 9.665 & 1296667.47 & $\begin{array}{l}\text { Daerah Cepat Maju dan } \\
\text { Cepat Tumbuh }\end{array}$ \\
\hline 4 & SWP Lawang & 8.974 & 1526120.31 & $\begin{array}{l}\text { Daerah Cepat Maju dan } \\
\text { Cepat Tumbuh }\end{array}$ \\
\hline 5 & $\begin{array}{l}\text { SWP Tumpang \& } \\
\text { sekitarnya }\end{array}$ & 7.509 & 995989.81 & Daerah Relatif Tertinggal \\
\hline 6 & $\begin{array}{l}\text { SWP Kepanjen \& } \\
\text { sekitarnya }\end{array}$ & 8.083 & 1275411.80 & Daerah Maju Tapi \\
\hline 7 & SWP Donomulyo & 7.026 & 981375.19 & Daerah Relatif Tertinggal \\
\hline 8 & $\begin{array}{l}\text { SWP Gondanglegi \& } \\
\text { sekitarnya }\end{array}$ & 6.745 & 1094867.45 & Daerah Relatif Tertinggal \\
\hline 9 & $\begin{array}{l}\text { SWP Dampit \& } \\
\text { sekitarnya }\end{array}$ & 7.263 & 1207497.38 & Daerah Maju Tapi \\
\hline
\end{tabular}

Sumber: Malang dan Jawa Timur Dalam Angka 2002 (diolah)

Klasifikasi wilayah berdasarkan pendapatan per kapita dan pertumbuhan dapat digambarkan dengan Tipologi Klassen, dapat dilihat seperti pada gambar 2. Dengan Tipologi Klassen, SWP yang ada di Kabupaten Malang dapat diklasifikasi menjadi empat pola pertumbuhan (lihat gambar 3) yaitu: Satuan Wilayah Pengembangan I, merupakan SWP yang tergolong daerah berkembang cepat. Ciri daerah mempunyai klasifikasi ini adalah daerah yang pertumbuhannya cepat namun pendapat per kapitanya masih dibawah pendapatan per kapita Kabupaten Malang. Sedangkan Satuan Wilayah Pengembangan II, III tergolong pada pola pertumbuhan wilayah "Cepat Maju dan Cepat Tumbuh", dimana pada umumnya wilayah ini maju baik dari segi pembangunan atau kecepatan pertumbuhan. SWP yang termasuk kategori Cepat Maju dan Cepat Tumbuh mempunyai pola pertumbuhan; pendapatan per kapita dan laju pertumbuhan PDRB SWP lebih besar dari Pendapatan per Kapita Kabupaten dan laju pertumbuhan PDRB kabupaten.

Sedangkan untuk Satuan Wilayah Pengembangan IV, VI, VII tergolong pada pola pertumbuhan wilayah "Relatif Tertinggal". SWP yang termasuk dalam kategori ini adalah SWP yang secara ekonomis sangat tertinggal, baik dari segi pertumbuhan ekonomi maupun pendapatan per kapita. Dengan kata lain, SWP-SWP dalam kategori ini adalah SWP yang paling buruk keadaanya dibandingkan SWP lain

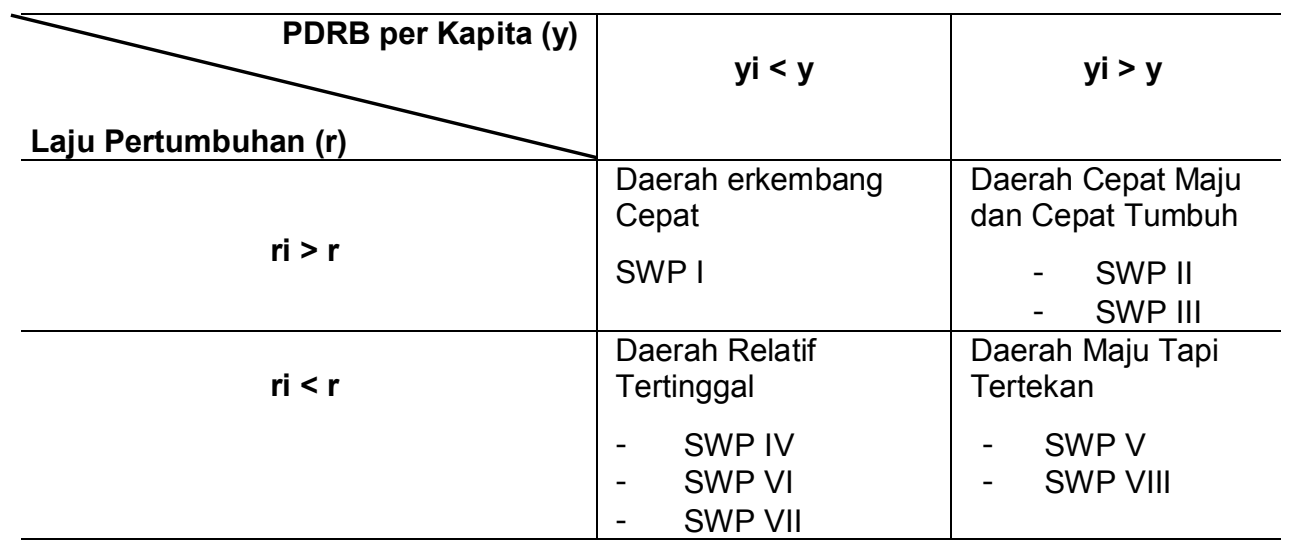

Gambar 2. Matrik Klasifikasi Pertumbuhan Ekonomi Satuan Wilayah Pengembangan (SWP) Menurut Analisis Tipologi Klassen 


\section{Analisis Daya Saing dan Potensi Daerah \\ Sutikno dan Maryunani}

di Kabupaten Malang. SWP yang termasuk kategori RelatifTertinggal mempunyai pola pertumbuhan; pendapatan per kapita dan laju pertumbuhan PDRB SWP lebih kecil dari pendapatan per kapita dan laju pertumbuhan PDRB kabupaten.

Dan untuk Satuan Wilayah Pengembangan V, VIII tergolong pada pola pertumbuhan wilayah "Maju Tapi Tertekan". SWP ini adalah SWP yang relatif maju tetapi dalam beberapa tahun mengalami pertumbuhan yang relatif kecil, akibat tertekannya kegiatan utama SWP yang bersangkutan. Pola pertumbuhan dari SWP ini yaitu; pendapatan per kapita SWP lebih besar dari pendapatan per kapita kabupaten dan laju pertumbuhan PDRB SWP lebih kecil dari laju pertumbuhan total PDRB kabupaten.

\section{Sub Sektor Unggulan SWP}

Penentuan sub sektor unggulan menggunakan alat analisis Location Quotient (LQ) dan Shift Share (SS). Kemudian dari hasil perhitungan dua alat analisis tersebut dilakukan pengkombinasian sehingga memunculkan tipe-tipe sub sektor unggulan dan bukan unggulan. Berikut adalah sub sektor unggulan di masing-masing SWP yang ada di Kabupaten Malang.

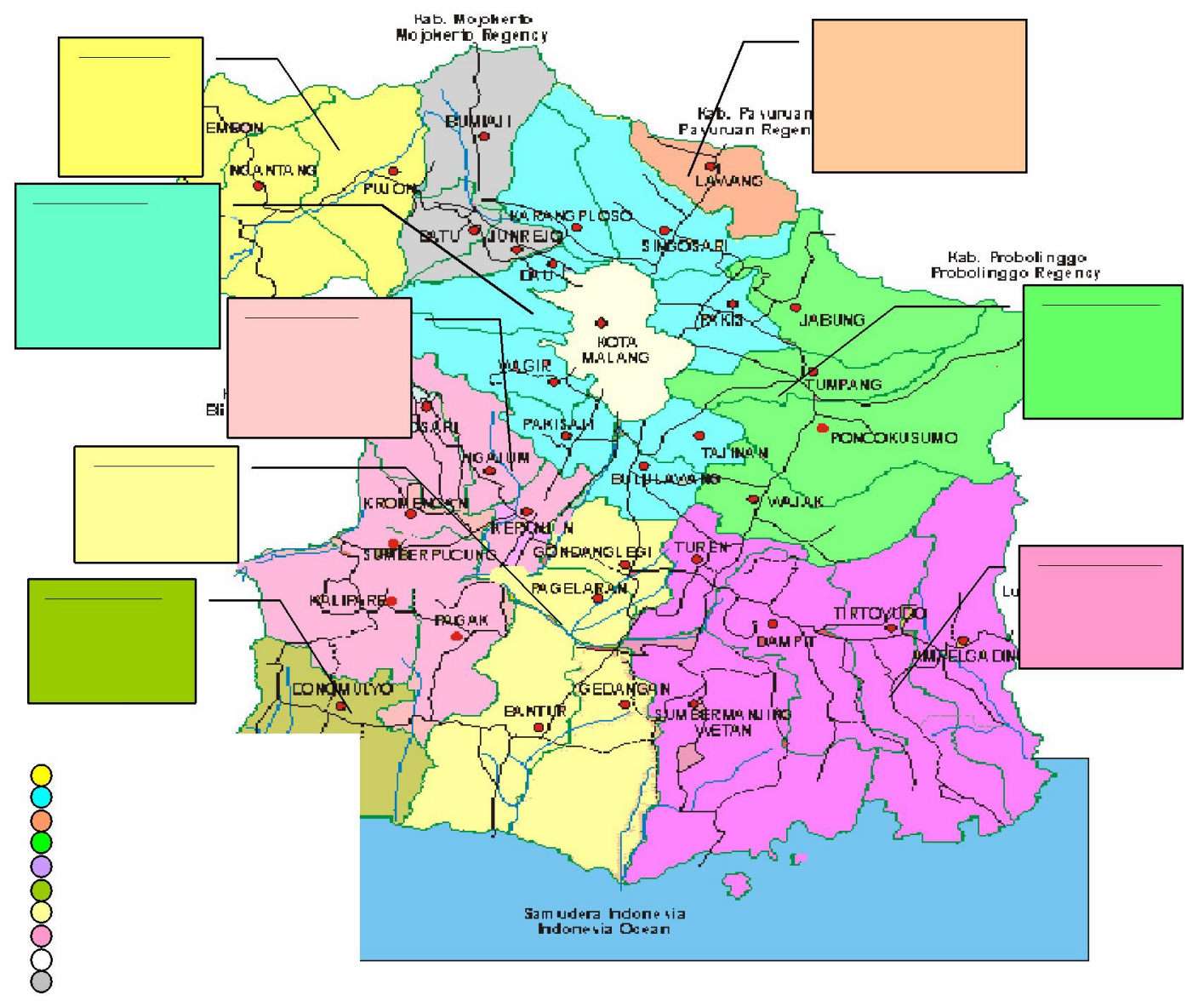

\section{Gambar 4. Peta Kabupaten Malang Dan Sub Sektor Unggulan Masing-Masing Satuan Wilayah Pengembangan (SWP)}

Berdasarkan perhitungan dan hasil analisis sub sektor di masing-masing SWP (seperti pada gambar di atas) menunjukkan bahwa Satuan Wilayah Pengembangan Lingkar kota Malang merupakan SWP yang mempunyai sub sektor paling banyak diantara SWP yang ada. SWP Lingkar Kota Malang mempunyai 10 sub sektor unggulan yaitu sub sektor; 1) Tanaman bahan makanan, 2) Makanan, minuman, dan tembakau, 3) Tekstil, kulit, dan alas kaki, 4) Barang dari kayu dan hasil hutan lain, 5) 
Pupuk kimia dan barang dari karet, 6) Alat angkutan, mesin, dan peralatan, 7) Barang-barang lain, 8) Pos dan telekomunikasi, 9) Lembaga keuangan bukan bank, serta 10) Hiburan dan kebudayaan.

Selain SWP Lingkar kota Malang, SWP Lawang juga merupakan SWP yang tergolong mempunyai sub sektor terbanyak diantara SWP yang ada. SWP Lawang mempunyai 9 sub sektor unggulan yaitu sub sektor; 1) Tanaman bahan makanan, 2) Tekstil, kulit, dan alas kaki, 3) Barang dari kayu dan hasil hutan lain, 4) Kertas dan barang cetakan, 5) Pupuk kimia dan barang dari karet, 6) Semen dan barang galian non logam, 7) Alat angkutan, mesin, dan peralatan, 8) Barang-barang lain, serta 9) Hotel.

Selanjutnya disusul oleh SWP Kepanjen dan sekitarnya yang mempunyai 8 sub sektor unggulan. Sub sektor unggulan yang dimiliki SWP Kepajen dan sekitarnya yaitu sub sektor; 1) Perdagangan, 2) Hotel, 3) Angkutan jalan raya, 4) Jasa penunjang angkutan, 5) Pos dan telekomunikasi, Bank, 6) Lembaga keuangan bukan bank, serta 7) Perorangan dan rumah tangga.

Sedangkan SWP yang mempunyai sub sektor unggulan sebanyak 7 adalah SWP Ngantang dan sekitarnya serta SWP Tumpang dan sekitarnya. Sektor unggulan yang dimiliki SWP Ngantang dan sekitarnya yaitu sub sektor; 1) Tanaman perkebunan, 2) Peternakan, 3) Kehutanan, 4) Perikanan, 5) Listrik, 6) Air Bersih, serta 7) Jasa Penunjang komunikasi. Sedangkan sektor unggulan yang dimiliki SWP Tumpang dan sekitarnya yaitu sub sektor; 1) Peternakan ,2) Kehutanan, 3) Penggalian, 4) Listrik, 5) Air bersih, 6) Sewa bangunan, serta 7) Hiburan dan kebudayaan.

Satuan Wilayah yang tergolong mempunyai sub sektor unggulan paling sedikit dibanding SWP lainnya adalah SWP Gondanglegi dan sekitarnya, SWP ini hanya memilki 5 sub sektor unggulan. Sementara SWP Dampit dan sekitarnya, serta SWP Donomulyo mempunyai 6 sub sektor ungggulan. Sektor unggulan yang dimiliki oleh SWP dan sekitarnya yaitu sub sektor; 1) Peternakan, 2) Kehutanan, 3) Perikanan, 4) Penggalian, serta 5) Listrik. Sementara Sub sektor unggulan yang dimiliki SWP Dampit dan sekitarnya yaitu sub sektor; 1) Tanaman perkebunan, 2) Perikanan, 3) Perdagangan, 4) Jasa penunjang komunikasi, 5) Bank, serta 6) Sosial kemasyarakatan. Sedangkan sub sektor unggulan yang dimiliki SWP Donomulyo yaitu sub sektor; 1) Peternakan, 2) Penggalian, 3) Jasa Perusahaan, 4) Pemerintahan umum, 5) Sosial kemasyarakatan, serta 6) Perorangan dan rumah.

\section{Pusat Pertumbuhan SWP}

Setelah melakukan identifikasi dan analisis terhadap masing-masing kecamatan yang ada di setiap Satuan Wilayah Pengembangan dengan menggunakan pendekatan kelengkapan fasilitas fisik, daya saing non fisik, dan jarak, maka diperoleh kecamatan sebagai prioritas pusat pertumbuhan di masingmasing SWP, seperti terdapat pada tabel di bawah ini.

Tabel 5. Kecamatan Prioritas Sebagai Pusat Pertumbuhan Masing-Masing SWP Berdasarkan Indikator Fasilitas Fisik, Fasilitas Non Fisik, dan Jarak

\begin{tabular}{|c|c|c|c|c|}
\hline \multirow{2}{*}{ No } & \multirow{2}{*}{$\begin{array}{c}\text { Satuan Wilayah } \\
\text { Pengembangan (SWP) }\end{array}$} & \multicolumn{2}{|c|}{$\begin{array}{l}\text { Kecamatan Prioritas Sebagai Pusat } \\
\text { Pertumbuhan SWP berdasarkan }\end{array}$} & \multirow{2}{*}{$\begin{array}{l}\text { Kecamatan } \\
\text { Prioritas }\end{array}$} \\
\hline & & $\begin{array}{l}\text { Fasilitas Fisik Dan } \\
\text { Fasilitas Non Fisik }\end{array}$ & Jarak & \\
\hline I & Ngantang \& sekitarnya & Ngantang, Pujon, Kasembon & Ngantang & Ngantang \\
\hline II & $\begin{array}{l}\text { Lingkar kota Malang Utara } \\
\text { Lingkar Kota Malang Selatan }\end{array}$ & $\begin{array}{l}\text { Singoari } \\
\text { Pakisaji }\end{array}$ & $\begin{array}{l}\text { Singosari } \\
\text { Bululawang }\end{array}$ & $\begin{array}{l}\text { Singosari } \\
\text { Pakisaji }\end{array}$ \\
\hline IV & Tumpang \& sekitarnya & Poncokusumo & Tumpang & Poncokusumo \\
\hline v & Kepanjen \& sekitarnya & Kepanjen, Sumberpucung & Kepanjen & Kepanjen \\
\hline VII & Gondanglegi \& sekitarnya & Gedangan, Pagelaran, Bantur & Pagelaran & Pagelaran \\
\hline VIII & Dampit \& sekitarnya & Turen & Turen & Turen \\
\hline
\end{tabular}




\section{Analisis Daya Saing dan Potensi Daerah \\ Sutikno dan Maryunani}

Penentuan kecamatan prioritas sebagai pusat pertumbuhan di masing-masing SWP menggunakan tiga indikator yaitu indikator; fasilitas fisik, fasilitas non fisik dan jarak. Suatu kecamatan bisa dikatakan sebagai kecamatan prioritas untuk dijadikan sebagai pusat pertumbuhan jika kecamatan tersebut termasuk kecamatan prioritas minimal pada 2 indikator dari 3 indikator yang ada.

Berdasarkan data pada tabel di atas menunjukkan bahwa kecamatan yang menjadi prioritas untuk dijadikan sebagai pusat pertumbuhan di Satuan Wilayah Ngantang dan sekitarnya (SWP I) adalah Kecamatan Ngantang. Kecamatan Ngantang termasuk kecamatan prioritas di dua indikator yaitu indikator; fasilitas fisik dan jarak, sedangkan untuk indikator non fisik kecamatan Ngantang menempati urutan ke 3. Untuk indikator ini kecamatan yang menjadi prioritas adalah kecamatan Kasembon.

Kecamatan Singosari merupakan kecamatan prioritas untuk dijadikan pusat pertumbuhan di Satuan Wilayah Pengembangan lingkar Kota Malang Utara (SWP II-Utara). Secamatan Singosari termasuk kecamatan prioritas untuk semua indikator yang ada. Sentara Untuk SWP-II Selatan Kecamatan Bululawang yang termasuk kecamatan prioritas pusat pertumbuhannya. Sedangkan untuk Satuan Wilayah Pengembangan Tumpang dan sekitarnya (SWP IV) kecamatan yang menjadi prioritas untuk dijadikan sebagai pusat pertumbuhannya adalah Kecamatan Poncokusumo. Kecamatan Poncokusumo merupakan kecamatan prioritas untuk indikator fasilitas fisik dan non fisik, sedangkan untuk indikator jarak menempati peringkat ke-2. untuk indikator jarak kecamatan yang menempati peringkat pertama adalah kecamatan Tumpang.

Dari tujuh kecamatan yang ada di Satuan Wilayah Pengembangan Kepanjen dan sekitarnya (SWP V), Kecamatan Kepanjen merupakan kecamatan prioritas sebagai pusat pertumbuhan. Kecamatan Kepanjen merupakan kecamatan prioritas di dua indikator yaitu; indikator fasilitas fisik dan jarak. Sementara untuk indikator fasilitas non fisik yang menjadi prioritas adalah Kecamatan Kromengan. Sedangkan kecamatan yang menjadi prioritas pusat pertumbuhan di Satuan Wilayah Pengembangan Gondanglegi dan sekitarnya (SWP VII) adalah Kecamatan Pagelaran.

Kecamatan Pagelaran merupakan kecamatan prioritas untuk indikator fasilitas non fisik dan jarak, sedangkan untuk indikator fasilitas fisik menempati urutan ke-3. Kecamatan yang menempati urutan ke-1 untuk indikator ini adalah kecamatan Gedangan.

Dari kelima kecamatan yang ada di Satuan Wilayah Pengembangan Dampit dan sekitarnya tidak ada satupun kecamatan yang mempunyai prioritas pada dua indikator. Kecamatan Turen menempati prioritas pertama untuk indikator fasilitas fisik, sementara untuk indikator fasilitas non fisik prioreitas pertama adalah kecamatan Sumbermanjing, sementara kecamatan Tirtoyudo menempati prioritas pertama untuk indikator jarak. Namun yang terpilih sebagai kecamatan prioritas untuk pusat pertumbuhan di SWPVIII adalah Kecamatan Turen. Alasan menyebabkan Kecamatan Turen sebagai prioritas, karena kecamatan Turen menempati prioritas kedua (peringkat ke-2) untuk dua indikator yaitu; indikator fasilitas non fisik dan jarak.

\section{E. Kesimpulan dan Implikasi Kebijakan}

\section{Kesimpulan}

Berdasarkan analisis kontribusi kelompok sektor ekonomi di masing-masing SPW, menunjukkan bahwa struktur ekonomi di semua SWP di dominasi oleh sektor tersier kemuadian diikuti oleh sektor primer dan sekunder (Tertier, Primer, dan Sekunder). Kecuali untuk SWP II dan SWP III, kedua SWP ini mempunyai struktur dimana sektor sekunder menempati posisi kedua (Tertier, Sekunder, dan Tertier). Atau kontribusi sektor sekunder lebih besar dibanding sektor primer untuk kedua SWP tersebut.

Sedangkan berdasarkan kontribusi masing-masing sektor menunjukan bahwa sektor pertanian, industri pengolahan, serta perdangan, hotel dan restoran merupakan sektor yang dominan kontribusinya terhadap PDRB di setiap SWP.

Berdasarkan analisis Tipologi Klasen diperoleh empat klasifikasi SWP yaitu: 1) SWP berkembang cepat, terdiri dari SWP I; 2) SWP maju dan cepat tumbuh, terdiri dari SWP II dan SWP III; 3) SWP 


\section{Journal of Indonesian Applied Economics \\ Vol.1 No.1 Oktober 2007, 1-17}

relatif tertinggal, terdiri dari SWP IV, SWP VI, dan SWPVII; serta 4) SWP maju tapi tertekan, terdiri dari SWP V dan SWP VIII.

Berdasarkan analisis Location Qoutient (LQ) dan Shift-Share (SS), maka diperoleh gambaran sektor unggulan di masing-masing SWP sebagai berikut: SWP I mempunyai sub sektor unggulan: 1) Tanaman perkebunan, 2) Peternakan, 3) Kehutanan, 4) Perikanan, 5) Listrik, 6) Air Bersih, 7) Jasa Penunjang komunikasi; SWP II mempunyai sub sektor unggulan: 1) Tanaman bahan makanan, 2) Makanan, minuman, dan tembakau, 3) Tekstil, kulit, \& alas kaki, 4) Barang dari kayu dan hasil hutan lain, 5) Pupuk kimia dan barang dari karet, 6) Alat angkutan, mesin dan peralatan, 7) Barang-barang lain, 8) Pos dan telekomunikasi, 9) Lembaga keuangan bukan bank, 10) Hiburan dan kebudayaan; SWP III mempunyai sub sektor unggulan: 1) Makanan, minuman, dan tembakau, 2) Tekstil, kulit, dan alas kaki, 3) Barang dari kayu dan hasil hutan lain, 4) Kertas dan barang cetakan, 5) Pupuk kimia dan barang dari karet, 6) Semen dan barang galian non logam, 7) Alat angkutan, mesin, dan peralatan, 8) Barang-barang lain, 9) Hotel; SWP IV mempunyai sub sektor unggulan: 1) Peternakan, 2) Kehutanan, 3) Penggalian, 4) Listrik, 5) Air bersih, 6) Sewa bangunan, 7) Hiburan dan kebudayaan; SWP V mempunyai sub sektor unggulan: 1) Perdagangan, 2) Hotel, 3) Angkutan jalan raya, 4) Jasa penunjang angkutan, 5) Pos dan telekomunikasi, 6) Bank, 7) Lembaga keuangan bukan bank, 8) Perorangan dan rumah tangga; SWP VI mempunyai sub sektor unggulan 1) Peternakan, 2) Penggalian, 3) Jasa Perusahaan, 4) Pemerintahan umum, 5) Sosial kemasyarakatan, 6) Perorangan dan rumah tangga; SWP VII mempunyai sub sektor unggulan: 1) Peternakan, 2) Kehutanan, 3) Perikanan, 4) Penggalian, 5) Listrik; SWP VIII mempunyai sub sektor unggulan: 1) Tanaman perkebunan, 2) Perikanan, 3) Perdagangan, 4) Jasa penunjang komunikasi, 5) Bank, 6) Sosial kemasyarakatan

Berdasarkan Analisis Scalogram, Daya Saing, dan Jarak, maka diperoleh gambaran pusat-pusat perturtumbuhan di masing-masing SWP sebagai berikut: 1) Kecamatan Ngantang merupakan kecamatan prioritas untuk pusat pertumbuhan SWP I; 2) Kecamatan Singosari merupakan kecamatan prioritas untuk pusat pertumbuhan SWP II Utara; 3) Kecamatan Pakisaji merupakan kecamatan prioritas untuk pusat pertumbuhan SWP II Selatan; 4) Kecamatan Poncokusumu merupakan kecamatan prioritas untuk pusat pertumbuhan SWP IV; 5) Kecamatan Kepanjen merupakan kecamatan prioritas untuk pusat pertumbuhan SWP V;6) Kecamatan Pagelalaran merupakan kecamatan prioritas untuk pusat pertumbuhan SWP VII; dan 7) Kecamatan Turen merupakan kecamatan prioritas untuk pusat pertumbuhan SWP VIII.

\section{Implikasi Kebijakan}

Berdasarkan hasil kesimpulan yang telah dipaparkan di atas, maka ada beberapa saran-saran yang diharapkan bisa menjadi masukan dalam menyempurnakan kebijakan wilayah pengembangan di Kabupaten Malang, antara lain:

1. Sektor Pertanian, Industri Pengolahan, dan Perdangan, Hotel dan Restoran merupakan sektor unggulan di setiap SWP. Jadi langkah yang paling urgen untuk meningkatkan pertumbuhan ekonomi yang berkaitan dengan sektoral di masing-masing SWP adalah sebagai berikut:

- Menyediakan fasilitas-fasilitas publik yang berkaitan dengan peningkatan aktivitas ekonomi yang berkaitan dengan tiga sektor ekonomi di atas.

- Pengembangan sektor-sektor tersebut hendaknya dilakukan secara terintegrasi, dimana pada akhirnya dapat meningkatkan penerimaan masyarakat maupun Pemerintah Daerah.

- Pengembangan industri pengolahan baik besar, menengah mapun kecil sebaiknya didukung oleh potensi sumber daya yang dimiliki, sehingga industri yang dikembangkan bertumpu pada kekuatan daerah dan mempunyai keterkaitan kebelakang maupun kedepan yang kuat agar tercipta struktur ekonomi yang kuat.

- Khusus untuk industri kecil terutama komoditi dengan ciri khas Malang perlu ditindak lanjuti dengan kebijakan dalam hal permodalan, teknik produksi, dan pemasaran. Kebijakan ini dapat berupa pelatihan, penyediaan informasi pasar, dukungan dinas terkait, lembaga keuangan, lembaga pengembangan swadaya masyarakat, swasta perguruan tinggi, dan sebagainya, 


\section{Analisis Daya Saing dan Potensi Daerah \\ Sutikno dan Maryunani}

sehingga komoditi khas Malang yang dihasilkan dari industri kecil dapat berkompetisi di pasar.

- Pemerintah Daerah Kabupaten Malang dan swasta daerah perlu tindakan pro aktif, konduktif dan konstruktif untuk merangsang tumbuhnya minat penanaman modal di daerah disertai dengan peningkatan dan pembenahan kualitas SDM melalui penyuluhan dan pelatihan untuk menciptakan tenaga kerja yang berkualitas

2. Wilayah Kabupaten Malang bagian utara merupakan wilayah yang mengalami pertumbuhan relatif lebih cepat dibandingkan wilayah Kabupaten Malang bagian selatan. Hal ini terlihat dari SWP (SWP I, II, III) yang ada di wilayah Utara tergolong SWP yang Berkembang cepat dan tergolong SWP yang Cepat Maju dan Cepat Tumbuh. Sementara SWP yang ada di wilayah bagian selatan tergolong SWP yang Relatif Tertinggal dan tergolong SWP yang Maju Tapi Tertekan. Gambaran ini menunjukkan bahwa telah terjadi kesenjangan pertumbuhan ekonomi antara wilayah Malang Utara dan Malang Selatan, sehingga membutuhkan kebijakan pemerintah berkaitan dengan pengembangan wilayah sebagai berikut:

- Pemerintah Kabupaten Malang sebaiknya meningkatkan peran sektor industri di wilayah Malang Selatan yang sesuai dengan karakter dan potensi wilayah tersebut. Sehingga tercipta industri yang berbasis pada potensi lokal, yang mungkin bisa saja berbeda dengan ciri industri yang ada di wilayah Malang Utara.

- Rendahnya pertumbuhan ekonomi di wilayah Malang Selatan disebabkan pula oleh aksesibilitas wilayah ini hanya satu arah, yaitu dari arah Malang Utara. Karena Wilayah Malang Selatan berbatasan langsung dengan Pantai Selatan. Untuk meningkatkan aksesibilitas terhadap wilayah Malang Selatan sebaiknya pemerintah membangun infrastruktur transportasi yang mendukung kelancaran aktivitas ekonomi. Seperti yang sudah direncanakan dengan pembangunan Jalan Lintas Malang Selatan (JLS).

- Khusus untuk SWP Lingkar Kota Malang Pemerintah perlu melakukan pemantauan khusus, mengingat tingginya pertumbuhan ekonomi di wilayah ini lebih banyak disebabkan oleh dampak dari perluasan aktivitas ekonomi di wilayah Kota Malang.

- Menggali potensi-potensi sektor ekonomi yang ada di wilayah Malang Selatan. melalui kerjasama dengan berbagai badan dan lembaga penelitian lainnya dalam bentuk riset dan pengembangan untuk mencari alternatif-alternatif pertumbuhan di masing-masing SWP yang tertinggal.

Kebijakan pembangunan daerah yang mengacu pada konsep pertumbuhan wilayah dengan mempertimbangkan potensi sektor ekonomi dan daya saing wilayah, dapat memberikan prioritas kepada kecamatan-kecamatan yang mempunyai keunggulan tersebut untuk menjadi pusat-pusat pertumbuhan wilayah, sehingga pelaksanaan pembangunan tidak terpusat hanya pada satu titik pertumbuhan yaitu di Kota Malang.

\section{DAFTAR PUSTAKA}

Abdullah, P., Alisjahbana, A., Effendi, N., Boediono. 2002. Daya Saing Daerah: Konsep dan Pengukurannya di Indonesia, BPFE Yogyakarta.

Arsyad Lincolin. 1997. Ekonomi Pembangunan (Edisi Ketiga), Yogyakarta: STIE-YKPN.

Arsyad Lincolin. 1999. Pengantar Perencanaan dan Pembangunan Ekonomi Daerah, BPFE, Yogyakarta

Badrudin Rudy. 1999. Pembangunan Wilayah Propinsi Istimewa Yogyakarta Pendekatan Teoritis. Jurnal Ekonomi Pembangunan, Vol. 4 No. 2 
Blakely, Edward. J. 1994. Planing Local Economic Development Theory and Practice, Second Edition, USA, Sage Publication.

Brojonegoro, Bambang P.S. 1999. The Impact of Currnt Economic Crisis to Regional Development Pattern in Indonesia, Paper, LPEM-FEUI, Jakarta.

BPS. (1998). 1996 Economic Census Complete Count Result: Indonesia, Jakarta: Biro Pusat Statistik.

Dick, H., Fox, J. J., \& Mackie, J. (Eds.). 1993. Balanced Development: East Java in the New Order, Singapore: Oxford University Press

Gujarati, Damodar. 1995. Basic Ekonometrics ( $3^{\text {rd }}$ edition ed), New York, Mc-Graw Hill, Inc

Haerudin, Andi. 2001. Identifikasi Kecamatan Sebagai Pusat Pertumbuhan Wilayah di Kabupaten Soppeng 1994/1995-1999/2000, Tesis S-2 Program Pascasarjana UGM, Tidak dipublikasikan.

Hill, H. 1996. The Indonesian Economy Since 1966: Southeast Asia's Emerging Giants, Cambridge: Cambridge University Press.

Isard, W. 1956. Location and Space Economy, Cambridge: MIT Press.

Juoro, U. 1989. Perkembangan Studi Ekonomi Aglomerasi dan Implikasi Bagi Perkembangan Perkotaan di Indonesia, Jurnal Ekonomi dan Keuangan Indonesia, Vol. 37 No. 2

Kadariah. 1985. Ekonomi Perencanaan, Lembaga Penerbit FE-UI

Kuncoro M. 2003. Metode Riset Untuk Bisnis dan Ekonomi (Bagaimana Meneliti dan Menulis Tesis), Erlangga, Jakarta.

Kuncoro M. 2001. Analisis Spasial dan Regional (Studi Aglomerasi dan Kluster Industri Indonesia, UPP AMPYKPN, Yogyakarta

Kuncoro, M., Adji, A., \& Pradiptyo. R. (1997). Ekonomi Industri: Teori, Kebijakan, dan Studi Empiris di Indonesia, Yogyakarta: Widya Sarana Informatika.

Kuncoro, M. (2000). Ekonomi Pembangunan: Teori, Masalah dan Kebijakan. (1st ed.), Yogyakarta: UPP AMPYKPN.

Maijidi, Nasyith. 1997. Anggaran Pembangunan dan Ketimpangan Ekonomi antar Daerah, Prisma, No. 3

Perroux. 1950. Economic Development Culture Change, Growth and Development, Hafner Publishing Company, New York

Setyarini, Djati. 1999. Faktor-Faktor yang Mempengaruhi Kesenjangan Pembangunan Ekonomi antar Daerah di Propinsi Jawa Tengah, Tesis S-2 Program Pascasarjana, UGM, Tidak dipublikasikan.

Sjafrizal. 1997. Pertumbuhan Ekonomi dan Ketimpangan Regional Wilayah Indonesia Bagian Barat, Prisma, LP3ES, No.3

Soepono, Prasetyo. 1998. Peranan Daerah Perkotaan Bagi Pembangunan Regional: Penerapan Model Van Thunen yang dimodifikasi di Indonesia, Junal Ekonomi dan Bisnis Indonesia. Vol. 13 No. 2 


\section{Analisis Daya Saing dan Potensi Daerah}

Sutikno dan Maryunani

Soepono, Prasetyo. 2000. Model Gravitasi sebagai Alat Pengukur Hinter Land dari Central Place suatu Tinjauan Teoritik, Jurnal Ekonomi dan Bisnis Vol. 15 No. 4

Soepono, Prasetyo. 1999. Teori Lokasi: Representasi Landasan Mikro Bagi Teori Pembangunan Daerah, Jurnal Ekonomi dan Bisnis, Vol. 14 No.4

Sukirno, Sadono. 1985. Ekonomi Pembangunan, LP3ES UI, Jakarta

Sutarno. 2002. Pertumbuhan Ekonomi dan Ketimpangan PDRB Per Kapita Antar Kecamatan Di Kabupaten Banyumas, (1993-2000), Tesis S-2 Program Pascasarjana UGM, Tidak dipublikasikan

Todaro, Michael, P. 2000. Pembangunan Ekonomi di Dunia Ketiga, Edisi Ketujuh (diterjemahkan oleh Haris Munandar), Erlangga, Jakarta

Warpani, Suwarjoko. 1983. Analisis Kota dan Daerah, Edisi ketiga, ITB Bandung

Wei, Y., Dennis and Fan, C., Cindy. 2000. Regional Inequality in China: Acase Study of Jiangsu Province, Asian Economic Journal, Vol 52

Williamson, J.G. 1965. Regional Inequality and The Process of National Development, a description of Pattern, Economic Development and Cultural Change, Vol. XXXVII No. 27, 11-13.

Ying, Long, G. 2000. China's Changing Regional Disparities during the Reform Period, Economic Geography, Vol. XXIV No. 7 